\title{
PROLONGED INCREASE OF CORTICOSTERONE SECRETION BY CHRONIC SOCIAL STRESS DOES NOT NECESSARILY IMPAIR IMMUNE FUNCTIONS
}

\author{
Frédéric Klein ${ }^{1,2}$, Valérie Lemaire ${ }^{1}$, Carmen Sand ${ }^{3}$ \\ Sergio Vitiello ${ }^{1}$, Jos Van der Logt ${ }^{4}$, Philippe E. Laurent ${ }^{2}$ \\ Pierre Neveu ${ }^{1}$, Michel Le Moal ${ }^{1}$, Pierre Mormède ${ }^{1}$ \\ 1 Laboratoire de Psychobiologie des Comportements Adaptatifs INSERM U259 - INRA, \\ Université de Bordeaux II, Rue Camille St Saëns, 33077 BORDEAUX, France \\ 2 Laboratoire L. Lafon 20, rue Charles Martigny, 94701 MAISONS ALFORT, France \\ 3 Department of Psychobiology, Instituto de Neurobiologia Santiago Ramon y Cajal, Calle \\ Dr. Arce 37, 28002 MADRID, Espagne \\ ${ }^{4}$ Laboratory for Medical Microbiology, Katholieke Universiteit Sint-Radboudziekenhuis, \\ Postbus 9101, NIJMEGEN, The Netherlands
}

(Received in final form January 7, 1992)

\begin{abstract}
Summary
The influence of a chronic social stress upon immunity was investigated in Wistar rats, submitted for four weeks to two different behavioral situations, balanced in a factorial design: housing with three females and membership rotation. The combination of these two factors led to adrenal enlargement (43.3\%), thymus involution (39.5\%) and increased basal corticosterone levels, all indices of activation of the hypothalamic-hypophysis-adrenal axis. However, neither natural killer cell activity, splenocyte reactivity to mitogen nor the rate of spontaneous development of antibodies against Mycoplasma pulmonis, a common pathogen of the respiratory tract, were changed in the endocrine activated animals. Analysis of the data on kinetics of stress at 1, 7 and 28 days after the initial mixing of the animals gave the same results. These data question the immunosuppressant activity usually conferred to corticosteroids, at least when adrenal hyperactivity is induced by chronic environmental stressors.
\end{abstract}

Selye (1) described adrenal enlargement, thymus involution and gastric ulcers as the three characteristic symptoms of a non-specific response of the organism to any demand made upon it, later labelled as the stress response (2). Adrenal and thymus changes are the direct consequence of the activation of the hypothalamic-hypophysis-adrenal axis, which can also be shown by the increase in plasma corticosteroid levels. Since "stress" has usually been found to reduce various immune processes (3), as do pharmacological amounts of synthetic glucocorticoids (4), the classical scheme is that stress is immunosuppressive through the release of adrenal steroids. The experimental picture is far from being so simple. On the one hand, both increases and decreases of immune responsiveness have been described after various stress procedures (5-7) and these changes are not always blocked by adrenalectomy (8-11). On the other hand, changes in immune responsiveness in stress situations can be shown without parallel modifications of the hypophyseal-adrenal axis (12). 
Acute stress situations usually trigger a large array of endocrine and autonomic responses, so that it is difficult to trace the mediators of stress on the immune system, apart from the well documented consequences of increased corticosteroid levels, such as thymus involution and changes in leukocyte number and differential counts. Conversely, chronic stress protocols can trigger more specific endocrine / autonomic responses, and this was best demonstrated in social situations (13-17), which are also more ethologically significant than usual laboratory stressors. However, much less is known about their consequences on immune functions (18). Early studies clearly demonstrated that the same experimental condition could be either beneficial or detrimental to the Individual's resistance to disease. In the late 60's, Gross and Siegel (19) showed that chickens maintained in a stressful social environment were more resistant to bacterial infections (such as $E$. coll), but more susceptible to viral infections (such as Marek's disease). Similarly, the selection of chickens for a high corticosteroid response to social stress was associated with an increased susceptibility to Marek's disease, but a reduced sensitivity to infection with $E$. coli $(20,21)$. Several authors also showed that the response of the immune system to social pressure, as well as the endocrine changes, is much dependant upon the hierarchical position of the animal $(22,23)$.

We therefore have studied the model of chronic social stress proposed by Taylor and collaborators (24) in more detail (25). We show here that despite a strong neuroendocrine stimulation induced by the combination of mixed-sex housing and membership rotation, as evidenced by the increase of adrenal weight and circulating corticosterone levels and by thymus involution, no change could be found in natural-killer activity or in the response of spleen lymphocytes to mitogen. Furthermore, the course of the spontaneous development of antibodies against Mycoplasma pulmonis, a common contaminant of the upper respiratory tract in laboratory rodents, was not modified. These data and others available from the literature challenge the concept of a general immunosuppressive action of corticosteroids.

\section{Methods}

Animals Pathogen free Wistar rats were purchased from IFFA-CREDO (L'Arbresle, France) and housed in a room with controled light cycle (L:D 12:12 hours, lights on at $06: 00)$ and temperature $\left(22 \pm 2^{\circ} \mathrm{C}\right)$, with free access to food and water. Females were housed three per cage and left undisturbed until the final phase of the experiment. Males were housed individually for four weeks before the different group housing conditions were introduced as described later. All males were vasectomized at least one week before initiating the stress paradigm.

Stress Protocol Chronic social stress was induced as described earlier (25), except that there was no prior testing of the animals for their spontaneous aggressiveness, since we have demonstrated in a previous paper (25) that this was not a crucial factor for the efficacy of the social stress protocol. Two factors were used to induce chronic stress: daily reassignment of group-housed male rats ("rotation" factor, labeled R), with or without females in the cages ("female" factor, labeled F). More specifically, all males were housed in groups of three per cage $(28 \times 43 \times 18 \mathrm{~cm})$. For half of the animals from each condition, group membership remained the same (R-). Group membership for the other animals changed everyday by rotation among cages according to a random permutation procedure $(\mathrm{R}+)$. All animals, however, were changed everyday into new cages with clean bedding, just before light offset. In addition, half the males in each condition were assigned to two subconditions according to the presence $(F+)$ or absence $(F-)$ of three females in the cage. These two factors, daily reassignment of males and presence of females, were balanced in a factorial design resulting in 4 subconditions ( $R-F-, R-F+, R+F-, R+F+)$. The procedure was continued for four weeks, unless otherwise stated. Animals were weighed every week. The number of animals in each experimental group is given in the legend of the figures.

Specific Designs

Experiment 1 The four experimental groups were run as described in the previous paragraph (R-F-, $R-F+, R+F-n=12 ; R+F+n=10$ at the end of the experiment). Blood was taken by retroorbital puncture under light ether anesthesia four days before initiation of chronic stress to measure antibody titer against Mycoplasma pulmonis. At the end of four weeks of stress, all rats were decapitated at the beginning of the light phase and trunk blood was collected in chilled tubes with EDTA. After centrifugation, aliquots of plasma were frozen for further assay of corticosterone and measurement of antibody titer. The spleen was aseptically removed to study spleen lymphocyte reactivity to concanavalin A and natural killer cell activity. The thymus and adrenals were collected and weighed. 
Experiment 2 This experiment was designed to study the kinetics of the different processes under study, after initiation of the stress protocol. Only the two extremes of the stress conditions were used (namely R-F-, $R+F+$ ). Other control groups were run at the same time: one group of control rats were individually housed and another group of animals were kept three per cage but the bedding was changed only twice a week to follow the general practice of the laboratory, and to allow for the study of a possible effect of an everyday cage change, which by itself is enough to activate the adrenocortical axis (26). A control blood sample was taken by retroorbital puncture 29 days before initiating the stress procedure. Rats were sacrificed 1 day (acute, $n=6$ per group), 7 days (subacute, $n=6$ per group), or 28 days (chronic, $n=6$ per group, except $R+F+, n=11$ ) after the initial grouping of the animals. Blood and organs were collected and processed as in experiment 1.

\section{Investigation of Immune Functions}

Preparation of spleen lymphocytes The spleen was removed aseptically immediatly after sacrifice and was dissociated in RPMI 1640 medium (Gibco, Glasgow, UK). Erythrocytes were lysed and after three washes, the number of cells was adjusted to $2.5 \times 10^{7} \mathrm{cell} / \mathrm{s} / \mathrm{ml}$ in medium containing $5 \%$ heat inactivated fetal calf serum, $1 \%$ mercaptoethanol and $1 \%$ antibiotic antimycotic solution (GIBCO).

Natural killer cell activity NK cell activity was tested by a ${ }^{51} \mathrm{Cr}$ release assay using YAC-1 cells, a Maloney virus-induced lymphoma, as target cells (Flow Laboratories, Puteaux, France). Cultured YAC-1 cells were labelled by incubating $1.0 \times 10^{7}$ cells with $100 \mu \mathrm{Ci}$ sodium $\left[{ }^{51} \mathrm{Cr}\right]$ chromate (New England Nuclear, Paris, France) for 1 hour at $37^{\circ} \mathrm{C}$, and washed. The mortality of labelled YAC-1 cells was lower than $10 \%$. Cytotoxicity was measured in triplicate samples at effector to target $(E / T)$ ratios from 100:1 to 12.5:1 using $2.5 \times 10^{4}$ YAC-1 target cells. After four hours of incubation at $37^{\circ} \mathrm{C}, 100 \mu \mathrm{l}$ aliquots of the supernatants were removed and the radioactivity was measured in a gamma-counter. Spontaneous or total release was assessed by incubating labelled YAC-1 cells with medium alone or with $3 \mathrm{M} \mathrm{HCl}$ repectively. NK activity was expressed as the ratio (CPM test $\left.-\mathrm{CPM}_{\text {spontaneous }}\right) /\left(\mathrm{CPM}_{\text {total }}-\mathrm{CPM}_{\text {spontaneous }}\right)$.

Mitogen-induced spleen lymphocyte activation Triplicates of spleen cell suspensions $\left(2 \times 10^{5}\right.$ cells/well) were cultured in 96-well tissue culture clusters with flat bottom wells (Nunc, Roskilde, Denmark), for three days in the presence of diluted mitogen in a humidified atmosphere of $5 \% \mathrm{CO}_{2}$ in air. Concanavalin A (ConA, DIFCO, Detroit, MI, USA) was used at final concentrations of 1,2 and $4 \mu \mathrm{g} / \mathrm{ml}$.

Cell activation was revealed by two different methods. In the first experiment, the metabolic activity of lymphocytes was measured by their ability to transform the substrate 3-(4,5-dimethylthiazol-2-yl) 2,5-diphenyl tetrazolium (MTT, Sigma, St Louis USA) into formazan according to Moosman (27). MTT (20 $\mu \mathrm{l} \mathrm{of} \mathrm{a} 5 \mathrm{mg} / \mathrm{ml}$ solution in PBS) was added to cell cultures for 4 hours. The cells was then lysed and formazan cristals dissolved with SDS (100 $\mu \mathrm{l}$ of a $10 \%$ solution). Twenty-four hours later, the optical density was measured at $550 \mathrm{~nm}$ in a multiwell spectrophotometer. In the second experiment, lymphocyte activation was measured both by MTT metabolism and by $\left[{ }^{3} \mathrm{H}\right]$ thymidine uptake, a direct index of lymphocyte mitotic activity. After 3 days of culture, tritiated thymidine $(2 \mu \mathrm{Ci}, 5 \mathrm{Ci} / \mathrm{mmol}$, CEA, France) was added in a volume of $50 \mu \mathrm{l}$. Twentyfour hours later, cells were collected on fiber-glass strips using a multichannel harvester. The filters were dried, scintillation medium was added (Lipoluma, LUMAC, Schaesberg, The Netherlands, $3 \mathrm{ml}$ ) and radioactivity was measured in a beta counter.

Antibodies against Mycoplasma pulmonis In order to obtain some information on immune reactivity of these rats, serum samples were screened for antibodies Ig $G$ against Mycoplasma pulmonis, a common host of the respiratory tract in laboratory rodents (28). Antibody levels were detected with an ELISA test, essentially the same as described by Cassel and collaborators (29). Mycoplasma Arthridis and Mycoplasma Pneumoniae were used as control antigens.

Corticosterone assay Plasma corticosterone levels were measured by a competitive protein binding assay (30), as described previously (31).

Data analysis Because hormone plasma levels, antibody titers, lymphocyte proliferation counts fitted a log-normal distribution, raw data were transformed to logarithmic scores before analysis. Results were submitted to analysis of variance. Rotation $(R+, R-)$ and females $(F+, F-)$ in experiment 1 , housing conditions (R-F-, $\mathrm{R}+\mathrm{F}+$, isolated, controls) in experiment 2 were treated as main independent factors. 
Lymphocyte/target ratio and mitogen concentrations were treated as repeated measures within the same animal. The Crunch statistical package (Crunch Software Co., Oakland, CA) was used. Means and standard errors are given in the text and shown in the figures.

\section{Results}

Body weight change was gradual over the four weeks. In the first experiment, both females and rotation significantly reduced the growth of rats $\left[F_{1,42}=66.3 ; p=0.001\right.$ and $F_{1,42}=7.1 ; p=0.005$ respectively] (fig 1a). In both experiments, $R+F+$ rats lost weight while control rats put on weight $(-9.1 \mathrm{~g}$ vs. $+56.4 \mathrm{~g}$ in the first experiment and $-15.7 \mathrm{~g}$ vs. $+50.2 \mathrm{~g}$ in the second experiment). No difference was found between the various control groups in the second experiment (group housing with daily or twice-weekly bedding change or isolated animals).
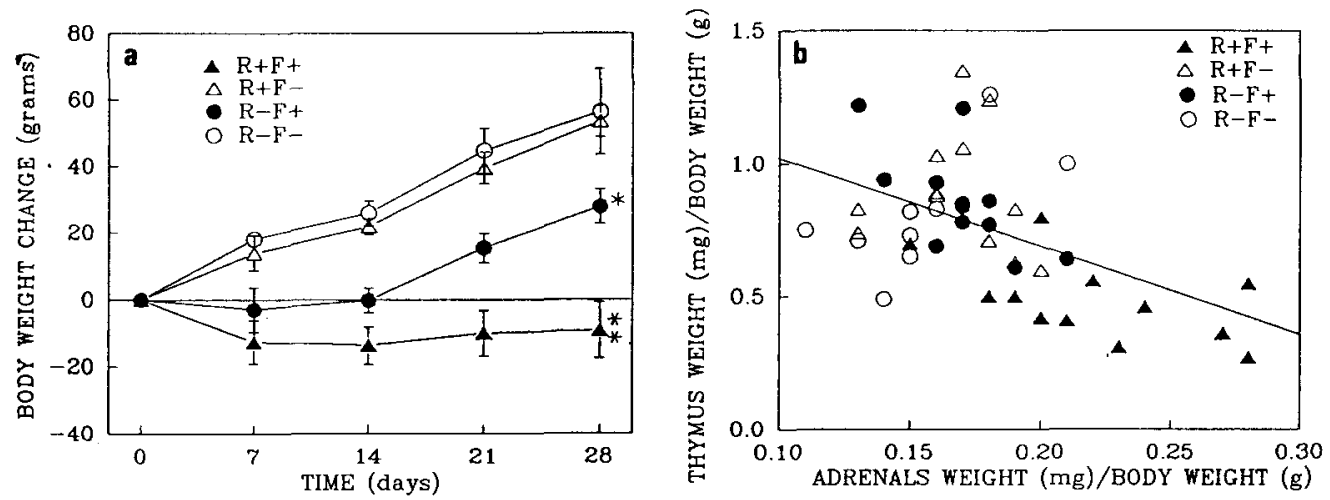

\section{FIG.1}

a: Kinetics of body weight changes during experiment 1 . Note the gradual change over the period of stress. $\left({ }^{\star} p<0.05 ;{ }^{\star \star} p<0.01\right.$ vs R-F-) b: Correlation between thymus and adrenal weight expressed as percentage of body weight (experiment 1). Organs were collected after 4 weeks of social stress. The correlation between thymus and adrenals weights was negative $(r=-0.51)$ and highly significant $(p<0.0005)$.

Adrenals were significantly enlarged in $R+F+$ animals compared to all other groups $(+43.3 \%$ in experiment 1 and $+26.8 \%$ in experiment 2). The kinetic study showed that the enlargement of adrenals developped progressively over time and was not yet significant by day 7 (fig 2).

Thymus weight was a mirror image of adrenal weight and these two measures were highly correlated (figure 1b). The kinetics of adrenal enlargement and thymus involution were also identical. The various control groups did not differ on either parameter (experiment 2, fig 2).

In the first experiment basal corticosterone levels were measured at the circadian trough in the morning and approximately 14 hours after the last mixing. They were three times higher in the $R+F+$ group compared to the R-F- control group (R+F+: $81.6 \mathrm{ng} / \mathrm{ml}$ vs $R-F-: 27.9 \mathrm{ng} / \mathrm{ml})$.

Adrenal enlargement, high circulating corticosterone levels and thymus shrinkage were clues of an overactive hypothalamic-hypophysis-adrenal axis induced by chronic social stress, as previously published (25). In this experiment, however, this activation was found in the $R+F+$ group only.

The natural killer activity of splenocytes was measured after 28 days of stress ( $1^{\text {st }}$ experiment, fig. 3 ). This activity was not modified by either experimental factor. The reactivity of splenocytes to concanavalin $A$ was evaluated by two different methods, the incorporation of tritiated thymidine which measures the synthetic activity of new DNA molecules during cell division and the metabolism of MTT by mitochondria, 
measuring cell activation $(27,32)$. Both measures gave the same negative results, with no difference between the various experimental conditions, whether acute or chronic. The results obtained with thymidine incorporation in the second experiment are shown in fig.4.

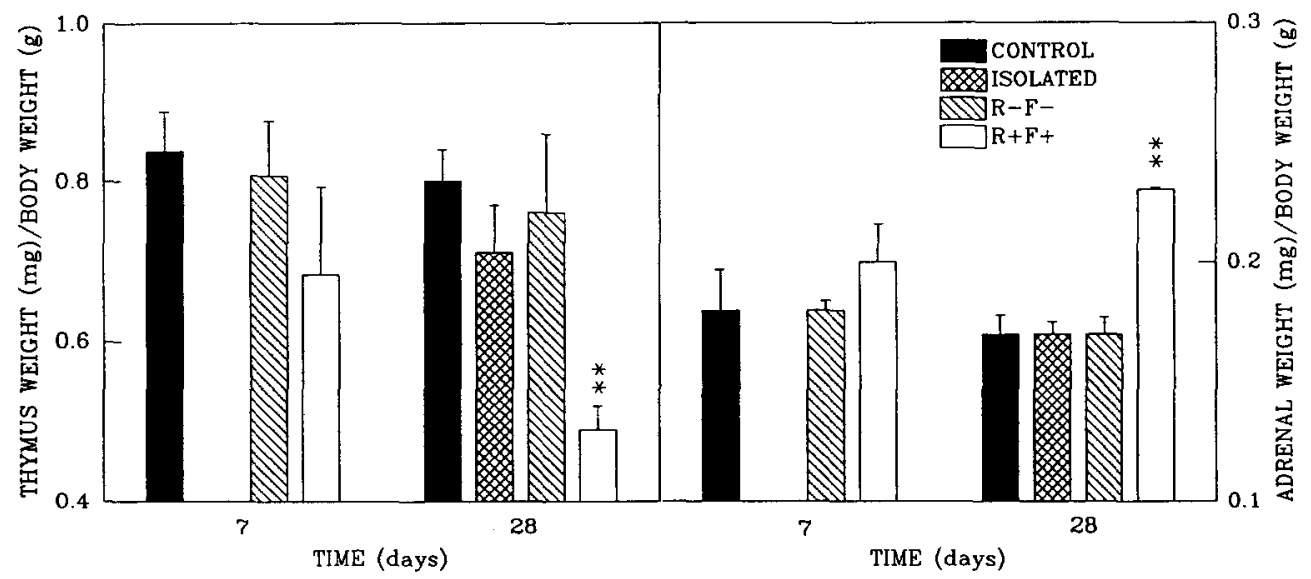

FIG.2

Adrenal and thymus weights expressed as percentage of body weight (experiment 2). In the $\mathrm{R}+\mathrm{F}+$ group, adrenals were heavier $\left(F_{1,15}=12.5 p<0.005\right)$ and thymus lighter $\left(F_{1,15}=8.9 p<0.01\right)$ than in the R-F-animals, only after 4 weeks of social stress $\left({ }^{\star \star} p<0.01\right)$.

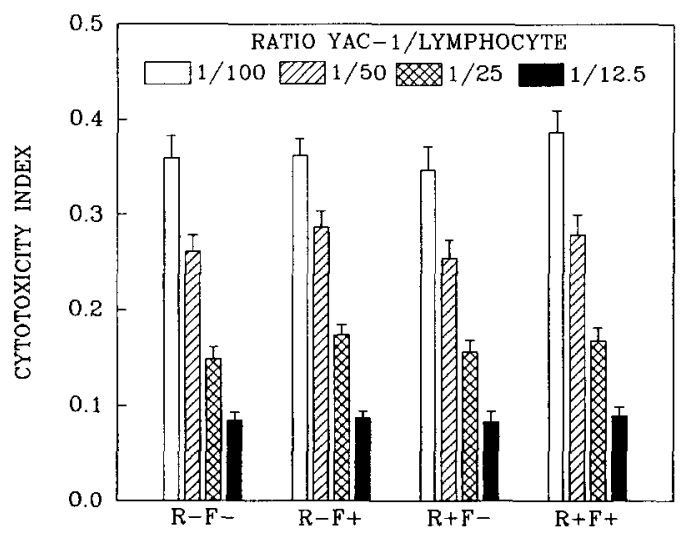

FIG.3

Natural killer cell activity of spleen lymphocytes of rats measured by the release of chromium from target YAC-1 cells. Spleen lymphocytes were incubated at four target to effector ratios (from 1/100 to 1/12.5). Albeit the cytotoxicity index of splenocytes fitted well the YAC-1/splenocyte ratio $\left(F_{3,126}=764.39 p<0.0001\right)$, it did not differ among experimental conditions (rotation factor $(R)$ $F_{1,42}=0.04$; female factor $(F) F_{1,42}=0.37$ ). 


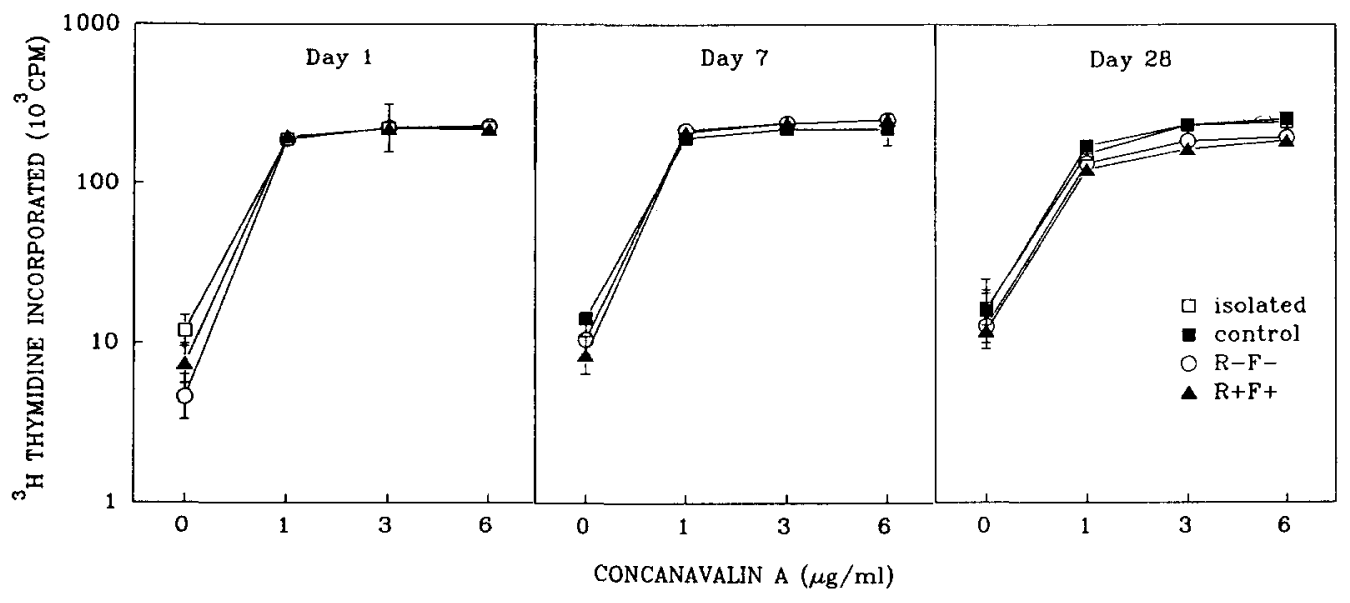

FIG.4

Splenocyte proliferation induced by increasing concentrations of concanavalin $A$ and assessed by the incorporation of radiolabelled thymidine into the DNA of dividing lymphocytes (expressed as counts per minute, cpm). Spleen cells were obtained from rats submitted to $1,7,28$ days of social stress. The splenocyte reactivity did not differ among experimental conditions (day $1: F_{2,15}=2.01$; day 7 : $F_{2,15}=0.21$; day $28: F_{3,22}=1.43$ [ 3 samples missing]).

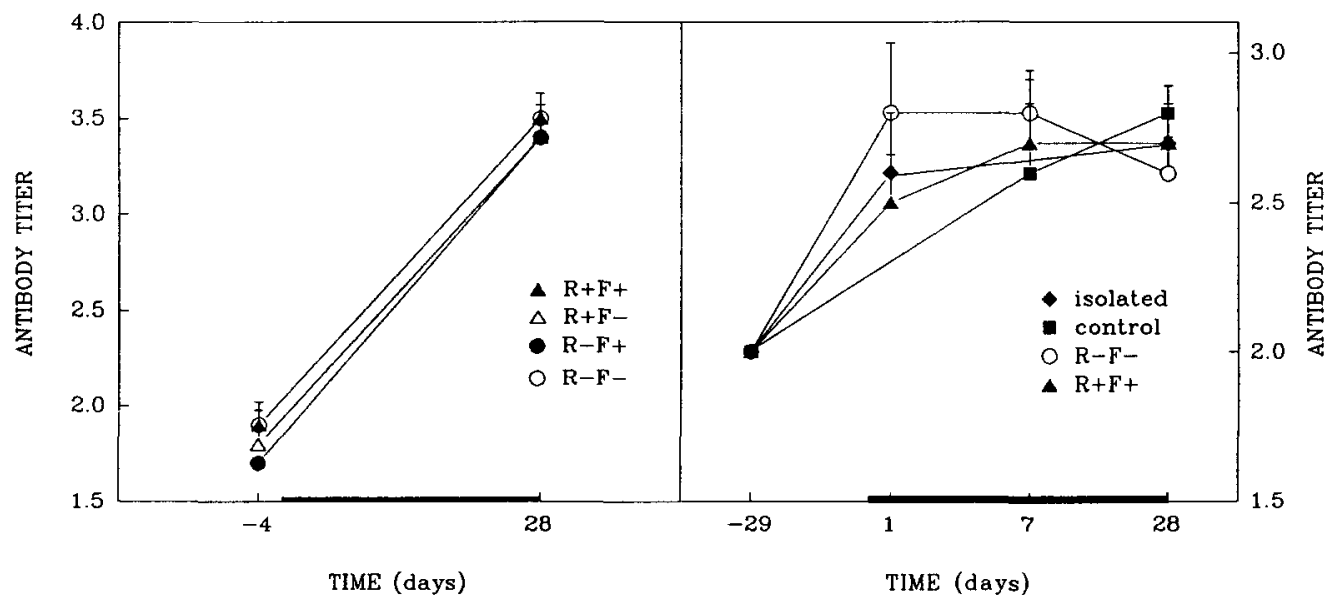

FIG.5

Spontaneous development of circulating antimycoplasma antibodies. Antibodies were quantified with ELISA. The thick line on the $X$ axis corresponds to the stress period. Note the log scale of the antibody titers. Evolution of the antibody titer was not modified by social stress or various experimental housing conditions. The left panel displays the antibody levels measured in the first experiment (rotation factor $(R): F_{1,42}=0.02$ and female factor $(F) F_{1,42}=0.03$ ) and in the right panel, in the $2^{\text {nd }}$ experiment (group factor, day $1: F_{2,14}=0.46$ (one sample missing), day $7: F_{2,15}=0.25$, day $28: F_{3,25}=0.48$ ).

The humoral response to the spontaneous infection by Mycoplasma pulmonis is shown in fig. 5 . Specific antibodies were absent in basal samples. The seroconversion for and increase of circulating antibody levels was different in the two experiments. Nevertheless no intergroup difference could be found. 


\section{Discussion}

The intensity of stress was clearly indicated by the depressed growth rate and morphological changes of adrenals and thymus. In those male rats rotating between mixed-sex colony cages, adrenal glands were enlarged by $26.8 \%$ (exp 2) to $43.3 \%$ (exp 1) and thymus was involuted by $39.5 \%$ (exp1) to $55.3 \%$ (exp 2). These changes were highly correlated within an experiment, the thymus weight being in the long term a very accurate indicator of integrated plasma free corticosteroid levels (33). The other groups, differing by only one experimental factor (rotation or coexistence with females), were previously shown to display intermedlate stress levels, differing in both intensity and quality of the response (25). Despite these activations of neuroendocrine / autonomic systems, no functional change of the immune system could be demonstrated, although two extreme approaches were used. The in vitro reactivity of spleen lymphocytes, exploring the natural-killer activity or the metabolic / mitotic response to plant lectin stimulation, is classically used in stress research and was shown to be sensitive to acute and chronic stressors, as well as to psychological factors of the situation, like behavioral coping opportunities, stressor predictability or social rank, and to genetic factors related to behavioral coping strategies $(9,12,22,23,34,35)$. On the other hand, the course of the specific antibody response to Mycoplasma pulmonis, after a spontaneous infection, was used as a global index of the efficiency of the immune system in vivo. Despite the very different antibody levels measured in the two experiments, stress did not modify their time course in any case, suggesting that these experimental situations did not influence the evolution of the disease nor the activity of the antibody generating mechanisms.

The complete lack of effect of the social stress paradigm on these various measures of immune functions is probably not the result of an early influence later compensated by counteracting mechanisms, as seen for instance by Irwin and Hauger (1988) after repeated restraint sessions (36), since the kinetic study consistently gave negative results as well at short ( 1 day) and intermediate ( 7 days) times. The experimental paradigms reporting immune changes with chronic stress, commonly employ repeated, high intensity stressors, such as electric shocks applied directly to the tail in restrained rats (37). Even repeated restraint alone, or footshock stress, although inducing a classical neuroendocrine response and changes in leukocyte numbers and populations, is not very effective in modifying leukocyte functions in long term experiments $(36,37)$, the details of the experimental design being of crucial importance (12). The kinetic study and the body weight curve clearly show that in the present experimental design, the development of the neuroendocrine changes are progressive over time.

On the other hand, it has been shown that the in-vitro response of blood lymphocytes to mitogens may be more sensitive to stress factors that spleen lymphocytes (10). Alternatively, the immunosuppressive effects of corticosteroids may have been overestimated from experiments using pharmacological amounts of potent synthetic glucocorticoids, and emphasizing their antiinflammatory properties (4). The significance of these experiments for the role of endogenous corticosteroids in physiologically relevant situations is questionable. Although there is no doubt that endogenous corticosteroids do regulate the inflammatory processes, as clearly demonstrated in autoimmune diseases (38-40), the generalization of these findings to other immune processes is far from being established. In fact, several immune responses were shown to be enhanced by various physiological conditions associated with an increased secretion of corticosteroids, such as dietary restriction $(41,42)$ or intense physical exercise $(43)$. Furthermore, many examples can be found of the positive role of corticosteroids in the normal function of lymphocytes $(44,45)$ and of dissociations between peripheral hypothalamic-hypophysis-adrenal axis activity and lymphocyte functions $(8,9,11,46,47)$

Munck and collaborators (4) have clearly underlined the contradiction between 1) the evidence that natural (cortisol and corticosterone) as well as synthetic corticosteroids (dexamethasone) act on the same glucocorticoid receptor to modulate immune functions and 2) the experimental finding that pharmacological doses are necessary to obtain these effects and that synthetic glucocorticoids like dexamethasone are tento-twenty times more active than cortisol and corticosterone. Recent advances in glucocorticoid receptor function may offer an answer to this paradox. Although cortisol and dexamethasone have similar affinity for the glucocorticoid receptor, there is a considerable discrepancy between these steroids in the activation of the receptor, with dexamethasone being far more active in this respect (48). Therefore, although dexamethasone interacts with the physiological glucocorticoid receptor, its interaction is of pharmacological nature and does not necessarily replicate the action of endogenous corticosteroids in physiological concentrations. 
Taken together these data suggest that several mediators are involved in the consequences of stressors on the immune system, and that among them, corticosteroids may not have the general immunosuppressive role usually conferred to them. Our results stress the fact that the effects described with synthetic glucocorticoids should be extended with caution to physiological situations, since long term increases of corticosteroids induced by chronic environmental challenges may be without obvious adverse consequences on several immune functions.

\section{Acknowledgements}

This work was supported by a grant from the Region Aquitaine, the Ministère de la Défense, Direction des Recherches et Etudes Techniques (DRET 89/059), and a twinning grant from the Institut National de la Santé et de la Recherche Médicale (INSERM, France) and the Consejo Superior de Investigaciones Cientificas (CSIC, Spain).

\section{References}

1. H. SELYE, Nature 138 32-33 (1936).

2. H. SELYE, American Scientist 61 692-699 (1973).

3. R. DANTZER and K.W. KELLEY, Life Sci. 44 1995-2008 (1989).

4. A. MUNCK, P.M. GUYRE and N.J. HOLBROOK, Endocr. Rev. 5 25-44 (1984).

5. F. BLECHA, R.A. BARRY and K.W. KELLEY, Proc. Soc. Exp. Biol. Med. 169 239-246 (1982).

6. G. CROISET, C. HEIJNEN, H.D. VELDHUIS, D. DE WIED and R.E. BAILLIEUX, Life Sci. 40 775-782 (1987).

7. D.T. LYSLE, J.E. CUNNICK and B.S. RABIN, Brain Behav. Immun. 4 269-277 (1990).

8. F. BLECHA, K.W. KELLEY and D.G. SATTERLEE, Proc. Soc. Exp. Biol. Med. 169 239-246 (1982).

9. S.E. KELLER, J.M. WEISS, S.J. SCHLEIFER, N.E. MILLER and M. STEIN, Science 221 1301-1304 (1983).

10. B.S. RABIN, J.E. CUNNICK and D.T. LYSLE, Prog. Neuroendocrinoimmmunol. 3 116-124 (1990).

11. R. JAIN, D. ZWICKLER, C.S. HOLLANDER, H. BRAND, A. SAPERSTEIN, B. HUTCHINSON, C. BROWN and T. AUDHYA, Endocrinology 128 1329-1336 (1991).

12. P. MORMEDE, R. DANTZER, B. MICHAUD, K.W. KELLEY and M. LE MOAL, Physiol. Behav. 43 577-583 (1988).

13. J. AXELROD, R.A. MUELLER, J.P. HENRY and P.M. STEPHEN, Nature 225 1059-1060 (1970).

14. R. DANTZER and P. MORMEDE, J. Anim. Sci. 57 6-18 (1983).

15. E.A. EDWARDS, R.H. RAHE, P.M. STEPHENS and J.P. HENRY, Proc. Soc. Exp. Biol. Med. 164 478-481 (1978).

16. P. MORMEDE, Social Stress in Farm Animals R. ZAYAN and R. DANTZER (eds) p. 203-211 Martinus Nijhof, The Hague (1990).

17. D. VON HOLST, J. Auton. Nerv. Syst., Suppl. $657-670$ (1986).

18. P. MORMEDE, Psychobiology of Stress S. PUGLISI-ALLEGRA and A. OLIVERIO (eds) p. 95-102 Kluwer Academic Publisher, Dordrecht (1990).

19. W.B. GROSS and P.B. SIEGEL, Poultry Sci. 44 898-1001 (1965).

20. W.B. GROSS and G. COLMANO, Poultry Sci. 50 1213-1217 (1971).

21. W.B. GROSS and P.B. SIEGEL, Avian Diseases 17 807-815 (1973).

22. J. KOOLHAAS and B. BOHUS Stress, Personal Control and Health, A. STEPTOE and A. APPELS (eds), p. 295-305 John Wiley \& Sons Ltd, Brussels (1989).

23. A. RAAB, R. DANTZER, B. MICHAUD, P. MORMEDE, K. TAGHZOUTI, H. SIMON and M. LE MOAL, Physiol. Behav. 36 223-228 (1986).

24. G.T. TAYLOR, J. WEISS and R. RUPICH, Physiol. Behav. 39 429-433 (1987).

25. P. MORMEDE, V. LEMAIRE, N. CASTANON, J. DULLUC, M. LAVAL and M. LE MOAL, Physiol. Behav. 47 1099-1105 (1990).

26. A. ARMARIO, J.L. MONTERO and J. BALASCH, Physiol. Behav. 37 559-561 (1986)

27. T. MOOSMAN, J. Immunol. Methods 65 55-63 (1983).

28. G.H. CASSEL, J.R. LINDSEY, H.J. BACKER and J.K. DAVIS, The Laboratory Rat. Biology and Diseases, Vol 1, H.J. BACKER, J.R. LINDSEY and S.H. WEISBROTH (eds), p. 244-284, Academic Press, London (1979).

29. G.H. CASSEL, J.R. LINDSEY, J.K. DAVIS, M.K. DAVIDSON, M.B. BROWN and J.G. MAYO, Lab. Anim. Sci. 31 676-682 (1981).

30. B.E.P. MURPHY, J. Clin. Endocrinol. 27 973-977 (1967). 
31. P. MORMEDE, Nature 302 345-346 (1983).

32. D. GERLER and N. THOMASSET, J. Immunol. Methods 94 57-63 (1986).

33. N. LEVIN, S.F. AKANA, L. JACOBSON, R.W. KUHN, P.K. SIITERI and M.F. DALLMAN, Endocrinology 121 1104-1110 (1987).

34. M.L. LAUDENSLAGER, S.M. RYAN, R.C. DRUGAN, R.L. HYSON and S.F. MAIER, Science 221 568-570 (1983).

35. C. SANDI, N. CASTANON, S. VITIELLO, P.J. NEVEU and P. MORMEDE, J. Neuroimmunol. $\underline{31}$ 27-33 (1991).

36. M.R. IRWIN and R.L. HAUGER, Neuropsychopharmacol. 1 239-242 (1988).

37. O.A. BATUMAN, D. SAJEWSKI, J.E. OTTENWELLER, D.L. PITMAN and B.H. NATELSON, Brain Behav. Immun. 4 105-117 (1990).

38. G. KROEMER, H.P. BREZINSCHEK, R. FAESSLER, K. SCHAUENSTEIN and G. WICK, Immunol. Today 9 163-165 (1988).

39. E.M. STERNBERG, J.M. HILL, G.P. CHROUSOS, T. KAMILARIS, S.J. LISTWAK, P.W. GOLD and R.L. WILDER, Proc. Natl. Acad. Sci. USA 86 2374-2378 (1988).

40. D. MASON, I. MacPHEE and F. ANTONI, Immunology 70 1-5 (1990).

41. K. HISHINUMA, T. NISHIMURA, A. KONNO, Y. HASHIMOTO and S. KIMURA, Ann. Nutr. Metab. 34 76-84 (1990).

42. R. WEINDRUCH and R.L. WALFORD The Retardation of Aging and Diseases by Dietary Restriction, R. WEINDRUCH and R.L. WALFORD (eds) C. Thomas, Springfield (1988).

43. B.A. PETERS, M. SOTHMANN and W.B. WEHRENBERG, Life Sci. 45 2239-2245 (1989).

44. A.J. DUNN, J. Recept. Res. 8 589-607 (1988).

45. D. EMILIE, M.C. CREVON, M.T. AUFFREDOU and P. GALANAUD, Eur. J. Immunol. 18 2043-2047 (1988).

46. J.J. McGLONE, E.A. LUMPKIN and R.L. NORMAN. Endocrinology 129 1653-1658 (1991)

47. M. IRWIN, W. VALE and C. RIVIER. Endocrinology 126 2837-2844 (1990)

48. R.L. SPENCER, E.A. YOUNG, P.H. CHOO and B.S. McEWEN, Brain Res. 514 37-48 (1990). 